\title{
PENERAPAN MODEL LEARNING TOGETHER DILENGKAPI DENGAN LKS TERBIMBING UNTUK MENINGKATKAN INTERAKSI SOSIAL DAN PRESTASI BELAJAR SISWA PADA MATERI STOIKIOMETRI KELAS X MIPA 5 SMAN 7 SURAKARTA TAHUN PELAJARAN 2017/2018
}

\author{
Rawa Dana Lestari, Sulistyo Saputro, dan Sri Retno Dwi Ariani \\ Program Studi Pendidikan Kimia, FKIP, Universitas Sebelas Maret, Surakarta, Indonesia \\ “Keperluan korespondensi, telp: +627812747869, email: rawadanalestari@gmail.com
}

\begin{abstract}
ABSTRAK
Penelitian ini bertujuan untuk meningkatkan interaksi sosial dan prestasi belajar siswa pada materi stoikiometri kelas X MIPA 5 SMA Negeri 7 Surakarta menggunakan model pembelajaran Learning Together (LT) dilengkapi dengan LKS terbimbing. Metode penelitian ini adalah penelitian tindakan kelas yang dilaksanakan dalam 2 siklus di kelas X MIPA 5 SMA Negeri 7 Surakarta. Tahapan tiap siklus pada penelitian ini meliputi tahap perencanaan, pelaksanaan tindakan, observasi, dan refleksi. Subjek penelitian ini adalah siswa kelas X MIPA 5 SMA Negeri 7 Surakarta. Data dan sumber data yang digunakan diperoleh dari guru, siswa, dan dokumentasi. Teknik pengumpulan data meliputi tes, observasi, angket, dan wawancara. Berdasarkan hasil penelitian disimpulkan bahwa penerapan model pembelajaran Learning Together (LT) dapat meningkatkan: (1) interaksi sosial siswa materi stoikiometri dilihat dari kenaikan persentase yaitu pra siklus $46 \%$, siklus I $67 \%$, dan siklus II $82 \%$; (2) prestasi belajar siswa dalam materi stoikiometri pada aspek pengetahuan siklus I $67 \%$ menjadi $82 \%$ pada siklus II, aspek sikap $79 \%$ pada siklus I dan $94 \%$ pada siklus II, dan keterampilan mencapai ketuntasan $100 \%$.
\end{abstract}

Kata kunci: Interaksi Sosial, Prestasi Belajar, Learning Together (LT), Stoikiometri, Penelitian Tindakan Kelas

\section{PENDAHULUAN}

Pendidikan merupakan salah satu hal yang terpenting dalam kehidupan dan memiliki peranan yang besar dalam meningkatkan kualitas Sumber Daya Manusia (SDM) yang berdaya saing tinggi [1]. Tujuan kurikulum 2013 yaitu untuk mempersiapkan manusia Indonesia agar memiliki kemampuan hidup sebagai pribadi dan warga Negara yang beriman, produktif, kreatif, inovatif, dan afektif serta mampu berkontribusi pada kehidupan bermasyarakat, berbangsa, bernegara, dan peradaban dunia [2]. Proses pembelajaran pada kurikulum 2013 berbasis Student Center Learning, yaitu mengutamakan keterlibatan siswa secara aktif dalam pembelajaran, sehingga guru hanya sebagai fasilitator dan evaluator. Untuk meningkatkan efisiensi dan efektivitas ketercapaian kompetensi lulusan maka diperlukan perencanaan pembelajaran, pelaksanaan proses pembelajaran serta nilai proses pembelajaran.

Hasil observasi pada bulan September sampai dengan bulan Oktober 2017 di SMA Negeri 7 Surakarta proses pembelajaran masih terfokus pada guru sehingga guru menjadi sumber utama pengetahuan bagi siswa. Sumber belajar di SMA Negeri 7 Surakarta masih terbatas sehingga siswa hanya mengandalkan catatan ketika guru mengajar dan terkadang catatan tersebut kurang lengkap sehingga siswa kesulitan untuk mempelajari kembali materi yang disampaikan oleh guru, sehingga memerlukan media dan sumber belajar 
tambahan untuk membantu proses pembelajaran. Salah satu media yang mendukung proses pembelajaran adalah LKS. LKS menurut Trianto (2011) adalah panduan siswa yang digunakan untuk melalukan kegiatan pemecahan masalah [3], sedangkan menurut Suryani dan Agung (2012) LKS adalah salah satu sarana belajar siswa yang dapat membantu siswa ataupun guru saat proses pembelajaran agar berjalan dengan baik [4]. LKS yang digunakan berisi ringkasan materi pembelajaran, contoh soal, dan latihan soal materi stoikiometri yang digunakan sebagai soal diskusi dalam pembelajaran.

Berdasarkan hasil observasi kelas yang paling pasif adalah kelas X MIPA 5 . Selain itu terdapat beberapa masalah diantaranya: 1) siswa kurang antusias mengikuti pembelajaran karena saat guru melontarkan pertanyaan kepada siswa respon yang diberikan dinilai masih kurang aktif, 2) kerjasama siswa dinilai masih kurang karena kurangnya interaksi antar siswa dan cenderung individualistik ketika mendapatkan tugas kelompok. Hal tersebut menunjukkan bahwa interaksi sosial di kelas X MIPA 5 masih rendah, hal ini didukung oleh data angket penilaian interaksi sosial pra siklus terdiri dari lima indikator yaitu kerjasama, persaingan, pertentangan, persesuaian, dan perpaduan yang menunjukkan sekitar $46 \%$ siswa memiliki interaksi sosial yang baik dan sekitar $54 \%$ interaksi sosialnya masih kurang. $\mathrm{Hal}$ tersebut didukung dengan hasil observasi dimana kerjasama siswa kurang saat berdiskusi, ketika guru melontarkan pertanyaan respon siswa kurang dan siswa harus ditunjuk terlebih dahulu untuk menjawab sehingga persaingan dikelas masih rendah. Interaksi sosial merupakan hubungan-hubungan sosial yang dinamis menyangkut hubungan antara orang perorangan, antara perseorangan dengan kelompok maupun antar kelompok [5]. Prestasi belajar pada Penilaian Tengah Semester di kelas tersebut ketuntasannya belum mencapai $75 \%$ dan rata-ratanya masih dibawah kelas yang lainnya. Hasil Penilaian Tengah Semester dapat dilihat pada Tabel 1.
Tabel 1. Penilaian Tengah Semester Kelas X MIPA Tahun Pelajaran 2017/2018

\begin{tabular}{ccc}
\hline Kelas & $\begin{array}{c}\text { Rata- } \\
\text { rata }\end{array}$ & Ketuntasan (\%) \\
\hline X MIPA 4 & 79 & 70 \\
X MIPA 5 & 78 & 73 \\
X MIPA 6 & 84 & 84 \\
\hline
\end{tabular}

Berdasarkan wawancara dengan guru pada tanggal 4 Desember 2017, pada tahun pelajaran sebelumnya materi yang dianggap sulit oleh siswa adalah materi stoikiometri. Salah satu cara meningkatkan proses pembelajaran di SMA Negeri 7 Surakarta yaitu dengan melibatkan siswa secara aktif dalam pembelajaran. Penggunaan metode mengajar yang tepat membantu mewujudkan tercapainya tujuan pembelajaran secara efektif dan efisien. Salah satu metode mengajar adalah metode pembelajaran kooperatif [6].

Gokkurt, dkk (2012) melakukan penelitian dengan membandingkan dua kelompok, yaitu kelompok yang menggunakan model Learning Together dan kelompok menggunakan metode konvensional. Hasil penelitiannya menunjukkan kelompok dengan model Learning Together memperoleh hasil belajar yang lebih baik karena meningkatnya interaksi sosial [7]. Hasil penelitian Rahmasari, dkk (2014) menyatakan bahwa penerapan model Learning Together dapat meningkatkan interaksi sosial dan prestasi belajar siswa, hal ini ditunjukkan dengan peningkatan persentase ketuntasan belajar siswa [8]. Arofah, dkk (2015) meneliti tentang penerapan model Learning Together, yang mana pada hasil penelitiannya menyebutkan bahwa penerapan model tersebut dapat meningkatkan hasil belajar siswa yang meliputi hasil belajar psikomotor, afektif, dan kognitif [9]. Berdasarkan hasil penelitian Celikker \& Aksan (2012) LKS dapat mebantu proses pembelajaran [10].

Berdasarkan uraian tersebut maka dilakukan penelitian tindakan kelas dengan judul "Penerapan model Learning Together untuk meningkatkan Interaksi Sosial dan Prestasi Belajar 
Siswa pada Materi Stoikiometri Kelas $X$ MIPA 5 SMA Negeri 7 Surakarta Tahun Pelajaran 2017/2018". Dengan demikian tujuan dari penelitian ini dapat tercapai apabila interaksi sosial dan prestasi belajar siswa meningkat dalam mempelajari materi stoikiometri.

\section{METODE PENELITIAN}

Penelitian ini merupakan Penelitian Tindakan Kelas (PTK) yang dilaksanakan dalam dua siklus dimana tiap siklus terdiri dari tahap perencanaan, pelaksanaan, observasi, dan refleksi [11]. Subjek penelitian adalah siswa kelas $X$ MIPA 5 SMA Negeri 7 Surakarta semester genap tahun pelajaran 2017/2018. Objek penelitian adalah interaksi sosial dan prestasi belajar yang terdiri dari aspek pengetahuan, sikap, dan keterampilan. Teknik pengumpulan data dilakukan dengan observasi, angket, tes, dan wawancara.

Instrumen pembelajaran rencana pelaksanaan pembelajaran (RPP) dan LKS. Instrumen penilaian terdiri dari instrumen pengetahuan, sikap, keterampilan, dan interaksi sosial. Sebelum digunakan, semua instrumen divalidasi terlebih dahulu. Instrumen pembelajaran dan instrumen keterampilan divalidasi menggunakan formula Gregory [12]. Instrumen sikap dan interaksi sosial setelah divalidasi lalu diujicobakan dan dianalisis hasilnya untuk mengetahui reliabilitasnya dengan menggunakan SPSS. Sedangkan Instrumen pengetahuan setelah divalidasi lalu diujicobakan dan hasilnya dianalisis dengan ITEMAN untuk mengetahui reliabilitas, tingkat kesukaran dan daya beda soal. Teknik analisis data yang digunakan adalah teknik triangulasi yang mengacu pada model analisis Miles dan Huberman yang meliputi reduksi data, penyajian data, dan penarikan kesimpulan serta verifikasi [13].

\section{HASIL DAN PEMBAHASAN}

Penelitian tindakan kelas ini dilakukan dalam dua siklus. Siklus I dilaksanakan selama $9 \mathrm{JP}$ yaitu 3 kali pertemuan 2 JP dan tiga kali pertemuan
$1 \mathrm{JP}$, evaluasi siklus I dilaksanakan di akhir pertemuan. Siklus II dilaksanakan dalam 2 kali pertemuan yaitu pertemuan untuk mengulas materi (2 JP) dan evaluasi siklus II (1 JP).

\section{Siklus I}

Perencanaan tindakan dalam siklus I meliputi penyusunan RPP, LKS terbimbing, penilaian aspek pengetahu-an, sikap, keterampilan, dan interaksi sosial siswa.

Pelaksanaan tindakan siklus I dilakukan dalam $9 \mathrm{JP}$, yaitu untuk penyampaian materi dilakukan selama 2 kali pertemuan 2 JP dan 2 kali pertemuan $1 \mathrm{JP}$, evaluasi siklus I dilakukan di akhir pertemuan untuk tes pengetahuan, penilaian angket sikap serta angket interaksi sosial 2 JP sedangkan untuk penilaian keterampilan 1 JP. Setiap pertemuan siswa diberikan materi secara singkat dan diberikan permasalahan yang harus diselesaikan secara berkelompok. Permasalahan yang diberikan tersebut berkaitan dengan materi yang disampaikan. Penilaian aspek interaksi sosial dan sikap untuk metode observasi silakukan saat kegitan berlangsung. Sedangkan untuk penilaian pengetahuan, angket sikap, angket interaksi sosial, dan keterampilan dilakukan saat evaluasi siklus I. Penilaian pengetahuan berupa soal objektif tipe pilihan ganda, penilaian aspek sikap meliputi sikap spiritual dan sosial (rasa ingin tahu, tanggungjawab, dan komunikatif) [14], penilaian interaksi sosial meliputi kerjasama, persaingan, pertentangan, dan persesuaian [15], sedangkan penilaian keterampilan meliputi keterampilan mengolah dan menganalisis data dan keterampilan menyajikan data [14]. Target ketuntasan yang telah ditetapkan yaitu sebesar $75 \%$ dengan KKM 75. Hasil penilaian tindakan selama siklus I dapat diliahat pada Tabel 2.

Tabel 2. Hasil Penilaian Siklus I

\begin{tabular}{ccc}
\hline Aspek & Ketuntasan (\%) & Kriteria \\
\hline Pengetahuan & 67 & BT \\
Sikap & 79 & $\mathrm{~T}$ \\
Keterampilan & 100 & $\mathrm{~T}$ \\
Interaksi Sosial & 67 & $\mathrm{BT}$ \\
\hline
\end{tabular}

${ }^{*} \mathrm{BT}$ : Belum Tuntas, $\mathrm{T}$ : Tuntas 
Berdasakan hasil evaluasi siklus I diketahui bahwa aspek sikap dan keterampilan sudah tuntas yaitu sikap $79 \%$ dan keterampilan $100 \%$, tetapi untuk sikap pada indikator rasa ingin tahu ketuntasannya masih rendah yaitu $65 \%$ dimana ketuntasan yang diharapkan adalah $75 \%$, hal ini dikarenakan siswa masih malu untuk bertanya baik bertanya kepada guru maupun bertanya kepada temannya, sedangkan untuk penilaian keterampilan dari kedua indikator yang dinilai diambil nilai optimum. Untuk penilaian aspek pengetahuan pada siklus I ketuntasan yang tercapai $67 \%$ dan dari kesembilan indikator kompetensi terdapat dua indikator yang belum tuntas yaitu indikator menganalisis data percobaan untuk membuktikan hipotesis Avogadro dan menerapkan penggunaan konsep mol untuk menyelesaikan ketuntasannya $66 \%$ dan indikator menerapkan penggunaan konsep mol untuk menyelesaikan perhitungan kimia ketuntasannya $71 \%$. Sedangkan batas ketuntasan yang ditetapkan adalah $75 \%$. Berdasarkan hasil observasi soal dan wawancara, siswa masih kesulitan dalam mengidentifikasi data yang disajikan dan bingung menentukan rumus mana yang akan digunakan, sebab lain yaitu karena masih banyak siswa yang malu bertanya saat diskusi sehingga beberapa siswa kurang memahami cara menyelesaikan soal. Hasil ketuntasan interaksi sosial siklus I terdapat sekitar $67 \%$ siswa sudah mencapai batas ketuntasan. Untuk ketuntasan tiap indikatornya hanya terdapat satu indikator yang sudah tuntas yaitu perpaduan, sedangkan indikator kerjasama, pertentangan, dan persesuaian ketuntasannya $70 \%$ dan untuk indikator persaingan ketuntasannya masih relatif rendah yaitu $58 \%$, sedangkan target ketuntasan siswa aspek interaksi sosial adalah $75 \%$. Berdasarkan hasil analisis kemungkinan ketidaktercapaian indikator tersebut dikarenakan siswa cenderung mengerjakan tugas sendiri-sendiri saat diskusi kelompok sehingga kerjasama kelompok dinilai masih kurang, dan cenderung pasif saat presentasi berlangsung, ketika guru melontarkan pertanyaan respon siswa masih rendah.
Berdasarkan hasil pembelajaran dan evaluasi pada siklus I diketahui bahwa target ketuntasan dalam penelitian belum tercapai pada aspek interaksi sosial dan pengetahuan serta satu indikator pada aspek sikap, sehingga masih diperlukan perbaikan pembelajaran dengan melanjutkan ke siklus II sehingga persentase ketuntasan disemua aspek dapat tuntas seluruhnya.

\section{Siklus II}

Pada siklus II materi yang dibahas difokuskan pada indikator kompetensi yang belum tercapai di siklus I yaitu menganalisis data percobaan untuk membuktikan hipotesis Avogadro dan menerapkan penggunaan konsep mol untuk menyelesaikan perhitungan kimia.

Pembelajaran pada siklus II dilakukan selama $3 \mathrm{JP}$, yaitu 2 JP untuk penyampaian materi dan $1 \mathrm{JP}$ untuk evaluasi siklus II yang meliputi tes pengetahuan, angket interaksi sosial dan angket sikap untuk mengetahui perubahan atau peningkatan pada siklus II. Hasil penilaian siklus II dapat dilihat pada Tabel 3.

Tabel 3. Hasil Penilaian Siklus II

\begin{tabular}{ccc}
\hline Aspek & $\begin{array}{c}\text { Ketuntasan } \\
(\%)\end{array}$ & Kriteria \\
\hline Pengetahuan & 82 & Tuntas \\
Sikap & 94 & Tuntas \\
Interaksi Sosial & 82 & Tuntas \\
\hline
\end{tabular}

Berdasarkan Tabel 3 dapat diketahui bahwa ketuntasan semua aspek telah tercapai serta seluruh indikator pada tiap aspek juga telah tercapai, sehingga penelitian ini diakhiri pada siklus II.

\section{Perbandingan Hasil Tindakan Antar- siklus}

Secara umum, histogram peningkatan persentase ketuntasan seluruh aspek disetiap siklus dapat dilihat pada Gambar 1. 


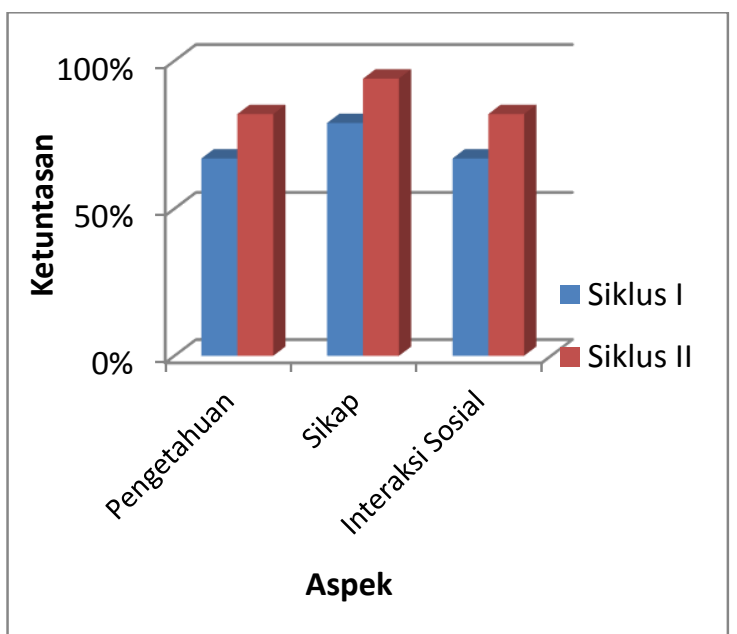

Gambar 1. Histogram Peningkatan

Persentase Ketuntasan

Berdasarkan Gambar 1, diketahui bahwa setelah diberi tindakan terjadi peningkatan persentase ketuntasan baik aspek pengetahuan, sikap, maupun aspek interaksi sosial. Persentase ketuntasan interaksi sosial pada siklus I $67 \%$ dan meningkat menjadi $82 \%$ pada siklus II. Persentase ketuntasan aspek sikap pada siklus I $79 \%$ dan pada siklus II meningkat menjadi 94\%. Sedangkan untuk aspek pengetahuan, persentase ketuntasan pada siklus I sebesar $67 \%$ dan pada siklus II meningkat menjadi $94 \%$.

\section{Pembahasan}

Berdasarkan hasil penelitian tindakan kelas yang telah dilakukan, dapat diketahui bahwa terjadi peningkatan persentase ketuntasan interaksi sosial dan prestasi belajar (sikap dan pengetahuan). Untuk aspek keterampilan tidak dilakukan penilaian di siklus II karena pada siklus I ketuntasannya sudah mencapai $100 \%$. Salah satu faktor yang menyebabkan terjadinya peningkatan prestasi belajar dan interaksi sosial siswa kelas X MIPA 5, menurut peneliti adalah model pembelajaran Learning Together.

Model pembelajaran Learning Together dapat meningkatkan interaksi sosial karena pada pembelajaran ini menuntut siswa untuk aktif dan saling bekerjasama secara kelompok agar diperoleh hasil yang baik dan dapat menyelesaikan permasalahan lebih cepat [11]. Hal ini sesuai dengan hasil penelitian Gokkurt, dkk (2012) yang menyebutkan bahwa penggunaan model pembelajaran Learning Together dapat meningkatkan interaksi sosial dan prestasi belajar siswa [7]. Penggunaan media LKS juga membantu siswa dalam mengikuti proses pembelajaran, seperti yang dikemukakan siswa saat wawancara bahwa LKS memberikan manfaat pada siswa untuk mempelajari materi yang disampaikan karena disekolah sumber belajar seperti buku sangat terbatas. Pernyataan tersebut didukung dengan hasil penelitian yang dilakukan oleh Celiker \& Aksan (2012) yang menyatakan bahwa LKS dapat membantu proses pembelajaran [10].

Secara keseluruhan, penelitian tindakan kelas dengan menerapkan model pembelajaran Learning Together pada materi stoikiometri dapat dikatakan berhasil karena seluruh indikator prestasi belajar dan indikator proses yang diukur telah mencapai target yang telah ditentukan. Jadi dapat disimpulkan bahwa penerapan model pembelajaran Learning Together yang dilengkapi dengan LKS terbimbing dapat meningkatkan interaksi sosial dan prestasi belajar siswa pada materi stoikiometri kelas X MIPA 5 SMA Negeri 7 Surakarta Tahun Pelajaran 2017/2018.

\section{KESIMPULAN}

Berdasarkan hasil penelitian, dapat disimpulkan bahwa penerapan model pembelajaran Learning Together dilengkapi dengan LKS terbimbing dapat meningkatkan interaksi sosial dan prestasi belajar siswa pada materi stoikiometri kelas X MIPA 5 SMA Negeri 7 Surakarta tahu pelajaran 2017/2018. Hal ini ditunjukkan dengan peningkatan persentase ketuntasan di setiap aspek pada siklus I dan siklus II.

\section{UCAPAN TERIMA KASIH}

Penulis mengucapkan terima kasih kepada kepala SMA Negeri 7 Surakarta yang telah memberikan izin dilakukannya penelitian di sekolah tersebut, guru kimia dan seluruh siswa kelas X MIPA 5 dan X MIPA 4 SMA Negeri 7 Surakarta tahun 
pelajaran 2017/2018 yang telah membantu dalam menyelesaikan penelitian ini.

\section{DAFTAR RUJUKAN}

[1] Arifin, Z. 2013. Evaluasi Pembelajaran, Bandung: PT Remaja Rosdakarya.

[2] Peraturan Menteri Pendidikan dan Kebudayaan Republik Indonesia Nomor 70 Tahun 2013 Tentang Kerangka Dasar dan Struktur Kurikulum Sekolah Menengah Kejuruan/ Madrasah Aliyah Kejuruan.

[3] Trianto. 2010. Perangkat Pembelajaran Terpadu. Jakarta: Prestasi Pustaka Publiser

[4] Suryani, N \& Agung, L. 2012. Strategi Belajar Mengajar. Yogyakarta: Penerbit Ombak

[5] Soekanto, Soerjono. 2002. Sosiologi Suatu Pengantar. Jakarta : RajaGrafindo Persada

[6] Lie, Anita. 2004. Cooperative Learning. Jakarta: Grasindo.

[7] Gokkurt, B., Dundar, S., Soylu, Y. \& Akgun, L. 2012. Procedia Social and Behavioral Sciences, 46, 3431-3434.
[8] Rahmasari, K. S., Utami, B \& Sugiharto. 2014. Jurnal Pendidikan Kimia 3(4), 155-161.

[9] Arofah, A. A., Sudiyanto \& Octoria, D. 2015. Jurnal Tata Arta UNS, 1(1), 125-134.

[10] Celikler, D \& Aksan, Z. 2012. Procedia - Social and Behavioral Sciences, 46, 4611-4614

[11] Arikunto, S., Suhardjono \& Supardi. 2008. Penelitian Tindakan Kelas. Jakarta : Bumi Aksara

[12] A. M. Miles, M., \& Huberman. 2009. Analisis Data Kualitatif. Jakarta: UI Press

[13] Slavin, Robert E. 2005. Cooperative Learning Teori, Riset dan Praktik. Bandung : Nusa Media

[14] Peraturan Menteri Pendidikan dan Kebudayaan Republik Indonesia Nomor 104 Tahun 2014 Tentang Penilaian Hasil Belajar oleh Pendidik pada Pendidikan Dasar dan Pendidikan Menengah

[15] Soekanto, S. 2002. Sosiologi Suatu Pengantar. Jakarta : Raja Grafindo Persada 